\title{
THE CIRCULATION IN ATHLETES 1
}

\author{
By HAROLD J. STEWART AND ROBERT F. WATSON \\ (From the Department of Medicine of the New York Hospital and Cornell University Medical \\ College, New York City)
}

(Received for publication August 1, 1939)

The effect of exercise on the dynamics of the circulation is still not precisely known, although the subject has been extensively studied. Most investigators $(1,2,3,4,5,6,7,8)$ have given attention to cardiac size, and very little study has been directed to the functional capacity of the hearts of individuals who have engaged in athletics. The effects of acute exercise (9) on the circulation, as well as the consequences of very prolonged and strenuous exercise $(10,11,12)$, have been studied. The data available up to 1933 have been reviewed by Steinhaus (13). The effects on the circulation of somewhat less strenuous and prolonged exercise, such as football and other college athletics, have not been properly estimated. A sufficient number of the school population in this country engage in college athletics to make pertinent an evaluation of their effects on the circulation.

In this investigation we have made certain studies of the circulation in a group of college athletes and compared them with measurements made by similar methods in a group of normal individuals engaged in ordinary sedentary occupations. These latter make up the control group. In these two groups we have made measurements of the arteriovenous oxygen differences, oxygen consumption, minute volume output of the heart, vital capacity, cardiac size, circulation time, venous pressure, arterial pressure and heart rate.

In the group of athletes, there are 14 healthy males between the ages of 19 and 23 years. All were members of a college football team at the time these observations were made and most of them participated also in other athletics such as basketball, baseball and track. ${ }^{2}$ The members of

\footnotetext{
1 Read by title at the Thirty-First Annual Meeting of the American Society for Clinical Investigation, Atlantic City, May 1, 1939.

2 We wish to thank Dr. William H. McCastline, University Medical Officer, Columbia University, for his kindness in referring the students to us, and to express our appreciation to the members of the football team for their hearty cooperation in this investigation.
}

this group had successfully engaged in competitive school and college athletics for periods of 2 to 9 years. They appeared to be representative of those engaged in college athletics.

The control group is comprised of 11 healthy males between the ages of 19 and 29 years who were engaged in sedentary occupations and indulged in no more than occasional mild athletic recreation. A complete history was taken and physical examination made on all members of both groups. Count of the red blood cells, estimation of the hemoglobin, Wassermann reaction in the blood, and routine examination of the urine were carried out. No abnormalities of the cardiovascularrenal system were detected.

\section{METHODS}

The subjects were admitted to the hospital overnight and all observations were made the following morning while the individuals were in a basal metabolic state. They were all trained to carry out the procedure beforehand. Measurements of the cardiac output were made by the acetylene method, three samples of gas being taken, as recommended by Grollman (14) in his book on "The Cardiac Output of Man in Health and Disease," and further elaborated by Grollman, Friedman, Clark, and Harrison (15). During the measurement, the individual was sitting in a steamer chair (angle $135^{\circ}$ ) with legs extended. While resting quietly, the radial pulse was counted at intervals of 5 minutes. At the end of one-half hour, the acetylene-air mixture was rebreathed. Three samples of gas were then taken during each rebreathing period for estimation of the arteriovenous oxygen difference. Two periods of rebreathing were carried out on each subject. Shortly afterwards, the oxygen consumption was measured with a Benedict-Roth spirometer. After a short interval, the vital capacity was measured and the height and weight recorded. Then the individual rested again, now lying down. In succession, sufficient time being allowed between each procedure for the patient to return to a basal metabolic state, an electrocardiogram was taken, the arm-to-tongue circulation time recorded, the venous pressure estimated, and the blood pressure measured. Finally, an x-ray photograph of the heart was made at a distance of two meters.

The arm-to-tongue circulation time was estimated by the use of Decholin: 5 cc. of a 20 per cent solution were injected rapidly ( 1 to 2 seconds) through an 18-gauge 
needle into an antecubital vein while the individual was lying quietly in the supine position. This was repeated in $11 / 2$ minutes after the first test had been elicited. The time was recorded from the beginning of the injection until the subject first perceived the bitter taste.

The venous pressure was measured by the direct method, using a large antecubital vein; the vein being placed on a level with the right auricle. The apparatus consisted of an L-shaped glass tube attached to a threeway stopcock, syringe and an 18-gauge needle. The apparatus was filled with a solution of sterile normal saline, a venipuncture performed, and the direct pressure readings recorded.

$\mathrm{X}$-ray photographs of the heart were taken with the subjects in the standing position, in full inspiration, at a distance of two meters. Measurements of the heart were carried out by the technique of Levy (16) and estimations of volume were made as recommended by Bardeen (17). In addition, measurements of the greatest transverse cardiac diameter and calculations of the cardiothoracic ratio were made.

\section{DATA}

The complete data for the athletes and normal control subjects are given in Tables I and II respectively. The measurements with the exception of cardiac size, are plotted as frequency diagrams in Figure 1.

The average value for the arteriovenous oxygen difference for the athletes was $63.9 \mathrm{cc}$., the range being from $73.9 \mathrm{cc}$. to $55.2 \mathrm{cc}$. For the control group the average value was $61.5 \mathrm{cc}$., the range being from $64.8 \mathrm{cc}$. to $56.1 \mathrm{cc}$. (Tables I, II and III) (Figure 1).

The average value for the cardiac index (cardiac output in liters per square meter of body surface area per minute) for the athletes was 2.12 liters, the range being from 2.67 liters to 1.75 liters. For the control group, the average value

TABLE I

Measurements of certain circulatory phenomena in 14 male athletes

\begin{tabular}{|c|c|c|c|c|c|c|c|c|c|c|c|c|c|c|c|c|c|c|c|c|c|c|c|}
\hline \multirow[b]{2}{*}{ 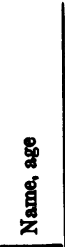 } & \multirow[b]{2}{*}{$\begin{array}{l}\text { 营 } \\
\text { 要 }\end{array}$} & \multirow[b]{2}{*}{ 疍 } & \multirow{2}{*}{ 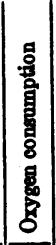 } & \multirow{2}{*}{ 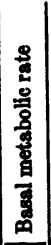 } & \multirow{2}{*}{ 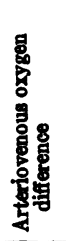 } & \multirow[b]{2}{*}{ 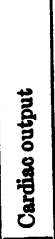 } & \multirow[b]{2}{*}{ 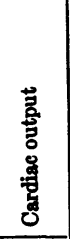 } & \multirow[b]{2}{*}{ 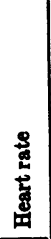 } & \multirow[b]{2}{*}{$\begin{array}{l}\text { 悬 } \\
\frac{8}{8} \\
\frac{9}{8} \\
\frac{8}{\infty}\end{array}$} & \multirow[b]{2}{*}{$\begin{array}{c}8 \\
8 \\
8 \\
8 \\
8 \\
8 \\
0\end{array}$} & \multirow[b]{2}{*}{ 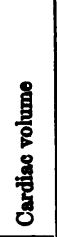 } & \multirow[b]{2}{*}{$\begin{array}{l}\frac{9}{3} \\
\frac{8}{2} \\
\frac{5}{5} \\
\frac{5}{5}\end{array}$} & \multirow{2}{*}{ 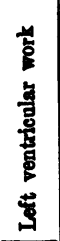 } & \multirow[b]{2}{*}{ 具 } & \multirow[b]{2}{*}{ 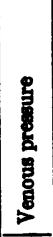 } & \multirow[b]{2}{*}{$\begin{array}{l}\text { 형 } \\
8 \\
\frac{8}{8} \\
\frac{5}{5} \\
5\end{array}$} & \multirow[b]{2}{*}{$\begin{array}{l}0 \\
8 \\
8 \\
8 \\
0 \\
0 \\
7 \\
\end{array}$} & \multirow[b]{2}{*}{ 용 } & \multirow[b]{2}{*}{$\begin{array}{l}\frac{8}{6} \\
\frac{1}{8} \\
\frac{8}{8} \\
\frac{8}{60}\end{array}$} & \multirow{2}{*}{ 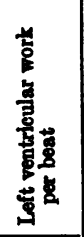 } & \multicolumn{3}{|c|}{ Heart measurements } \\
\hline & & & & & & & & & & & & & & & & & & & & & 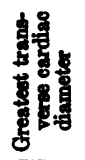 & 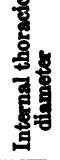 & 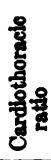 \\
\hline $\begin{array}{l}\text { years } \\
\text { J. } \mathrm{Ba} \text {. }\end{array}$ & $\begin{array}{l}\mathrm{cm} . \\
171.0\end{array}$ & kom. & $\begin{array}{c}c c . \\
\text { per } \\
\min - \\
\text { ute } \\
214\end{array}$ & $\begin{array}{l}\text { per } \\
\text { cent } \\
\\
-24\end{array}$ & $\begin{array}{l}c c . \\
61.2\end{array}$ & $\begin{array}{c}\text { liters } \\
\text { per } \\
\text { min- } \\
\text { ute } \\
3.50\end{array}$ & $\begin{array}{c}\text { liters } \\
\text { per eq. } \\
\text { m. per } \\
\text { minute } \\
1.76\end{array}$ & $\begin{array}{c}\text { per } \\
\text { min- } \\
\text { ut6 } \\
68\end{array}$ & $\begin{array}{c}c c . \\
\text { per } \\
\text { beat } \\
52\end{array}$ & $\begin{array}{c}q . \\
\text { cm. } \\
116.1\end{array}$ & $\begin{array}{c}\infty . \\
604.2\end{array}$ & $\begin{array}{c}\operatorname{mm}_{\boldsymbol{H} g} \\
105 / 60\end{array}$ & $\begin{array}{c}\text { gm. } \\
\text { m. } \\
\text { per } \\
\text { beat } \\
58.7\end{array}$ & $\begin{array}{c}\text { sec } \\
\text { onds } \\
15.4\end{array}$ & $\begin{array}{l}\mathrm{cm} . \\
10.4\end{array}$ & $\begin{array}{l}c . \\
4900\end{array}$ & $\begin{array}{l}\text { mil } \\
\text { lions } \\
5.15\end{array}$ & $\begin{array}{c}\text { per } \\
\text { cent } \\
108\end{array}$ & $\begin{array}{c}c c . \\
\text { per } \\
\text { kgm. } \\
\text { wt. } \\
0.60\end{array}$ & $\begin{array}{c}\text { om. m. } \\
\text { per kom. } \\
\text { body wt. } \\
0.68\end{array}$ & $\begin{array}{l}\mathrm{cm} . \\
12.6\end{array}$ & $\begin{array}{c}\mathrm{cm} . \\
\mathbf{3 1 . 0}\end{array}$ & $\begin{array}{c}\text { per } \\
\text { cent } \\
41.6\end{array}$ \\
\hline $\begin{array}{c}\text { J. Be. } \\
19\end{array}$ & 178.3 & 91.3 & 310 & 0 & 57.6 & 5.38 & 2.54 & 80 & 67 & 158.9 & 287.4 & $125 / 80$ & 98.4 & 13.3 & 10.1 & 6200 & 5.40 & 128 & 0.73 & 1.08 & 14.4 & 33.0 & 43.6 \\
\hline $\begin{array}{c}\text { J. Ca. } \\
21\end{array}$ & 175.5 & 79.5 & 286 & +1 & 66.4 & 4.31 & 2.20 & 80 & 54 & 110.6 & 562.3 & $124 / 80$ & 74.9 & 16.0 & 8.4 & 4200 & 5.25 & 135 & 0.68 & 0.94 & 11.6 & 30.5 & 38.0 \\
\hline H. C. & 177.0 & 80.1 & 255 & -11 & 59.5 & 4.30 & 2.16 & 70 & 61 & 140.7 & 795.6 & $110 / 66$ & 73.0 & 14.0 & 11.3 & 5100 & & & 0.76 & 0.91 & 13.9 & 30.1 & 46.2 \\
\hline J Co. & 170.5 & 79.8 & 286 & +5 & 55.9 & 5.12 & 2.67 & 94 & 54 & 129.5 & 711.3 & $115 / 80$ & 72.0 & 15.4 & 7.9 & 4600 & 5.80 & 140 & 0.68 & 0.90 & 13.3 & 31.2 & 42.6 \\
\hline J. D. & 176.3 & 84.1 & 280 & -2 & 73.0 & 3.84 & 1.92 & 66 & 60 & 144.0 & 834.8 & $118 / 78$ & 80.0 & 16.8 & 9.2 & 4600 & 5.50 & 105 & 0.71 & 0.95 & 14.4 & 31.8 & 45.0 \\
\hline G. H. & 174.3 & 75.8 & 274 & -14 & 73.9 & 3.71 & 1.80 & 66 & 56 & 118.4 & 622.8 & $110 / 80$ & 72.4 & 12.0 & 8.1 & 5250 & 5.25 & 128 & 0.74 & 0.95 & 11.7 & $\mathbf{3 0 . 0}$ & 39.0 \\
\hline J. N. & 177.5 & 73.2 & 236 & -13 & 70.0 & 3.37 & 1.77 & 48 & 70 & 141.5 & 813.6 & $122 / 85$ & 99.0 & 16.2 & 9.6 & 4100 & 5.15 & 127 & 0.96 & 1.35 & 14.3 & 30.0 & 47.7 \\
\hline N.P. & 172.3 & 82.6 & 249 & -10 & 55.5 & 4.50 & 2.28 & 60 & 75 & 113.2 & 580.4 & $120 / 85$ & 105.0 & 11.6 & 10.1 & 5150 & 6.10 & 110 & 0.91 & 1.27 & 12.0 & 30.8 & 38.9 \\
\hline W 8. & 176.5 & 82.2 & 292 & 0 & 62.0 & 4.71 & 2.35 & 56 & 84 & 144.4 & 837.4 & $110 / 70$ & 102.8 & 20.1 & 6.1 & 4800 & 5.90 & 105 & 1.02 & 1.25 & 13.9 & $\mathbf{3 0 . 5}$ & 45.6 \\
\hline B. 8. & 183.8 & 92.5 & 271 & -12 & 71.7 & 3.78 & 1.75 & 64 & 59 & 151.2 & 897.8 & $114 / 80$ & 77.8 & 17.1 & 9.1 & 5300 & 5.70 & 128 & 0.64 & 0.84 & 14.1 & 32.8 & 42.9 \\
\hline A. W. & 170.3 & 76.9 & 267 & 0 & 60.0 & 4.45 & 2.34 & 60 & 74 & 127.7 & 704.9 & $118 / 80$ & 99.6 & 14.6 & 8.7 & 4300 & 4.50 & 97 & 0.96 & 1.30 & 13.6 & 30.3 & 44.9 \\
\hline $\begin{array}{c}\text { H. W. } \\
20\end{array}$ & 179.0 & 72.1 & 238 & -12 & 55.2 & 4.81 & 2.27 & 58 & 74 & 132.8 & 739.9 & $108 / 75$ & 106.0 & 15.4 & 9.7 & 4600 & 4.70 & 116 & 1.03 & 1.47 & 12.7 & 31.1 & 40.8 \\
\hline 8. W. & 182.5 & 84.1 & 274 & -10 & 72.4 & 3.79 & 1.82 & 60 & 63 & 129.6 & 711.8 & $105 / 80$ & 79.7 & 17.3 & 9.7 & 5150 & 5.15 & 125 & 0.76 & 0.94 & 18.2 & 30.6 & 43.1 \\
\hline
\end{tabular}



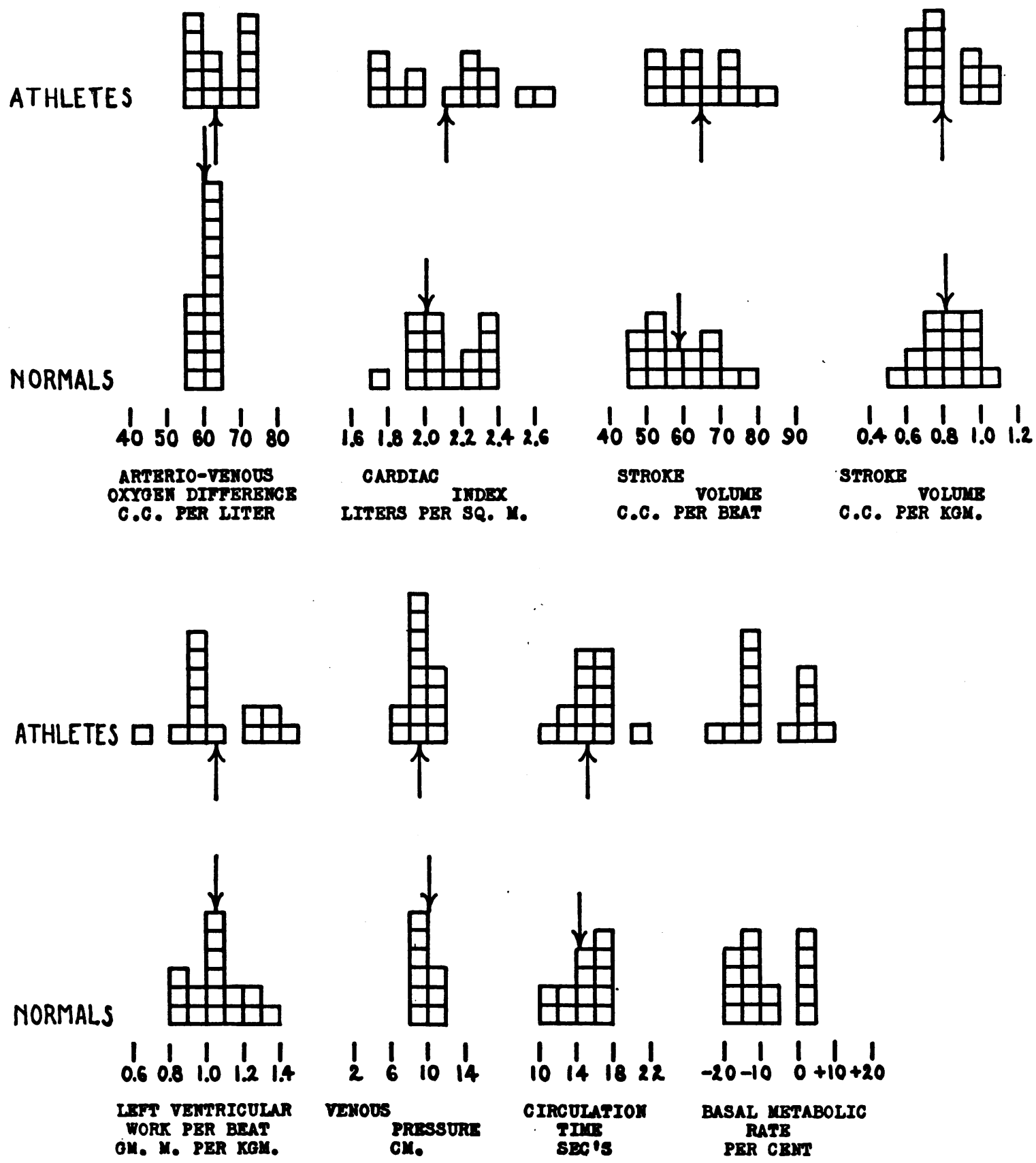

Fig. 1. Measurements of the Circulation in Athletes and Normal Subjects

In this figure the data relating to the measurements of the circulation in the normal group and in the athletes are plotted as frequency diagrams (Tables I and II). Each square is a unit and represents one measurement, and they are piled on top of one another when there is recurrence of that increment for the measurement in that particular group. The increments are as follows: arteriovenous oxygen difference, 5 cc.; cardiac index, 0.1 liter per square meter; stroke volume, $5 \mathrm{cc}$. per beat; stroke volume per kilogram, $0.1 \mathrm{cc}$; left ventricular work per beat, 0.1 gm.m. per kilogram; venous pressure, $2.0 \mathrm{~cm}$. of physiologic saline; circulation time, 2.0 seconds; and basal metabolic rate, 5 per cent. The mean values for each group of measurements are indicated by an arrow. 
TABLE II

Measurements of certain circulatory phenomena in 11 normal male individuals, by techniques similar to those used for the athletes

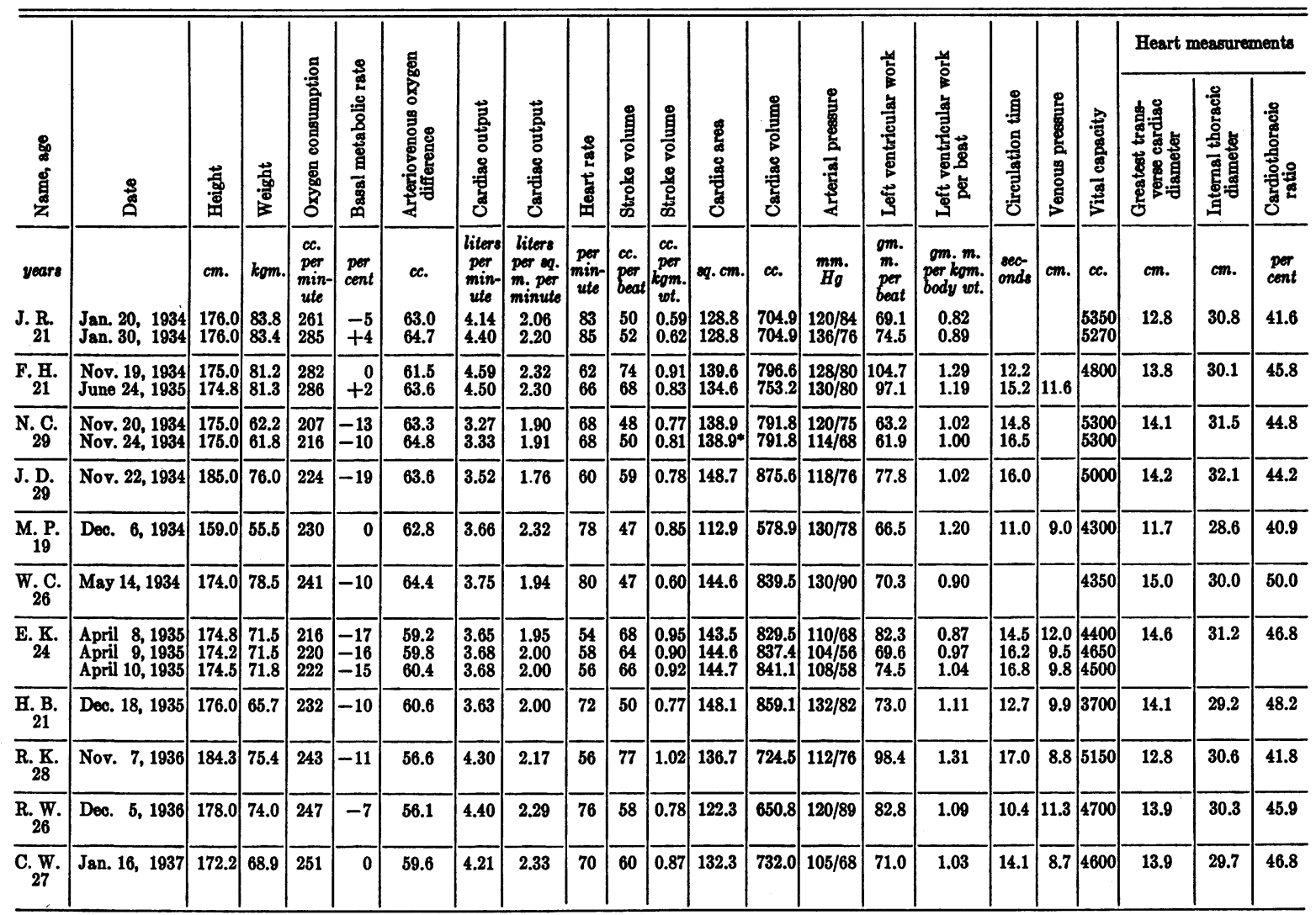

* X-ray of the heart was not repeated in this case and the previous measurements were used for cardiac area and volume.

was 2.09 liters, the range being from 2.33 liters to 1.76 liters (Tables I, II and III) (Figure 1).

The average value for the stroke volume in the athletes was $65 \mathrm{cc}$. with the maximum and minimum values of $84 \mathrm{cc}$. and $52 \mathrm{cc}$. respectively. The average for the control group was $59 \mathrm{cc}$., the range being $77 \mathrm{cc}$. to $47 \mathrm{cc}$. (Tables I, II and III) (Figure 1).

The average value for the stroke volume per kilogram of body weight for the athletes was 0.80 cc., the range being from $1.03 \mathrm{cc}$. to $0.60 \mathrm{cc}$. The average value for the control group was $0.81 \mathrm{cc}$, the range being from $1.02 \mathrm{cc}$. to $0.59 \mathrm{cc}$. (Tables I, II and III) (Figure 1).

The average value for the left ventricular work per beat per kilogram of body weight for the athletes was 1.06 gm.m. per $\mathrm{kgm}$., the range being from $1.47 \mathrm{gm} . \mathrm{m}$ per $\mathrm{kgm}$. to $0.68 \mathrm{gm} . \mathrm{m}$. per $\mathrm{kgm}$. For the control group the value was 1.05 gm.m. per kgm., the range being from 1.31 gm.m. per kgm. to 0.82 gm.m. per $\mathrm{kgm}$. (Tables I, II and III) (Figure 1).

The average value for the venous pressure for the athletes was $9.2 \mathrm{~cm}$. of physiologic saline, the range being from $11.3 \mathrm{~cm}$.' to $6.1 \mathrm{~cm}$. For the control group, the average. value was $10.1 \mathrm{~cm}$., the range being from $12.0 \mathrm{~cm}$. to $8.7 \mathrm{~cm}$. (Tables I, II and III) (Figure 1).

The average value for the arm-to-tongue circulation time for the athletes was 15.4 seconds, the range being from 20.1 seconds to 11.6 seconds. The average value for the control group was 14.4 seconds, the range being from 17.0 seconds to 10.4 seconds (Tables I, II and III) (Figure 1).

The heart size based on measurements of the transverse cardiac diameter was considered to be within the limits of normal in every subject in both groups. The average value of this diameter 
TABLE III

Average and range of values of certain measurements of the circulation in 14 male athletes and 11 normal male subjects

\begin{tabular}{|c|c|c|c|c|c|c|}
\hline & \multicolumn{3}{|c|}{ Normal } & \multicolumn{3}{|c|}{ Athletes } \\
\hline & \multirow{2}{*}{$\begin{array}{c}\text { A ver- } \\
\text { age }\end{array}$} & \multicolumn{2}{|c|}{ Range } & \multirow{2}{*}{$\begin{array}{c}\text { Aver- } \\
\text { age }\end{array}$} & \multicolumn{2}{|c|}{ Range } \\
\hline & & $\begin{array}{c}\text { Max- } \\
\text { imumum }\end{array}$ & $\underset{\text { imum }}{\text { Min- }}$ & & $\underset{\text { imum }}{\text { Max- }}$ & $\underset{\text { imum }}{\text { Min- }}$ \\
\hline 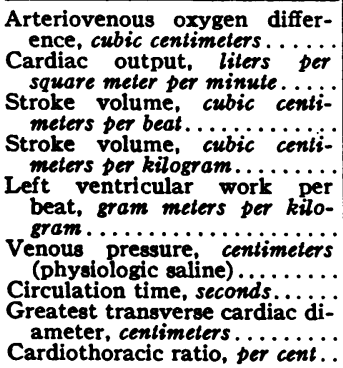 & $\begin{array}{c}61.5 \\
2.09 \\
59 \\
0.81 \\
1.05 \\
10.1 \\
14.4 \\
13.7 \\
45.2\end{array}$ & \begin{tabular}{|c|}
64.8 \\
2.33 \\
77 \\
1.02 \\
\\
1.31 \\
12.0 \\
17.0 \\
15 \\
50.0
\end{tabular} & $\begin{array}{c}56.1 \\
1.76 \\
47 \\
0.59 \\
\\
0.82 \\
8.7 \\
10.4 \\
11.7 \\
40.9\end{array}$ & $\begin{array}{c}63.9 \\
2.12 \\
65 \\
0.80 \\
1.06 \\
9.2 \\
15.4 \\
13.3 \\
42.9\end{array}$ & $\begin{array}{c}73.9 \\
2.67 \\
84 \\
1.03 \\
1.47 \\
11.3 \\
20.1 \\
14.4 \\
47.7\end{array}$ & \begin{tabular}{|c}
55.2 \\
1.75 \\
52 \\
0.60 \\
\\
0.68 \\
6.1 \\
11.6 \\
11.6 \\
38.0
\end{tabular} \\
\hline
\end{tabular}

for the athletes was $13.3 \mathrm{~cm}$., and for the control group $13.7 \mathrm{~cm}$. The average value for the cardiothoracic ratio for the athletes was 42.9 per cent, and 45.2 per cent for the control group (Tables I, II and III). The greatest transverse cardiac diameter did not exceed $15.0 \mathrm{~cm}$. nor did the cardiothoracic ratio exceed 50.0 per cent (Table III).

While the standard lead electrocardiograms were recorded for each subject in both groups, chest leads, derived by placing the right arm electrode just within the apex and the left arm electrode in the left interscapular region, were taken of 5 of the control subjects and of 13 of the 14 athletes. Normal sinus rhythm was present in all, and in each case the auriculoventricular and intraventricular conduction times were within the limits of normal. The R-T segment deviation did not exceed $1 \mathrm{~mm}$. and the T-waves in leads I and II were upright and more than $3 \mathrm{~mm}$. in amplitude. The amplitude of the QRS complexes exceeded $5 \mathrm{~mm}$. in two or more leads in every instance. Only 1 individual of each group showed a significant axis deviation (J. N., Table I and N. C., Table II) which was to the left. The chest lead was considered normal in every subject in which it was obtained.

\section{DISCUSSION}

It appears that there is no significant difference between the average values of the athletes and the control normal group for the arteriovenous oxygen difference, cardiac index (cardiac output in liters per square meter of body surface area per minute), stroke volume per kilogram of body weight, and the left ventricular work per beat per kilogram of body weight It is also apparent that the individual variations for these measurements are within the accepted limits of normal in every case for both groups. Our values for these measurements of the circulation are in agreement with those obtained by Grollman (14) on a group of 50 young, normal adults. The average value for the stroke volume of the athletes, however, is found to be appreciably greater than that of the normal subjects. This difference is apparently due to a difference in the average size (body surface area and weight) of the individuals, as the cardiac index and the stroke volume per kilogram of body weight, as stated above, show no significant differences in the two groups.

The average values for the circulation time and venous pressure in the two groups show no significant difference. Tarr and his associates (18) found that the normal value for the circulation time (Decholin) in their group fell between 10.0 seconds and 16.0 seconds. In our normal subjects, the individual estimations ranged from 10.4 seconds to 17.0 seconds. With one exception (W. S., Table I, 20.1 seconds), the athletes fell in the normal range. The measurements of the venous pressure, cardiac output and cardiac size of this individual were, however, within the limits of normal.

The work of the left ventricle per beat has been plotted against the cardiac volume (Figure 2). In a statistical study Starr and his associates have shown that in the presence of normal circulatory function the work of the left ventricle is proportional to the size of the heart $(19,20)$. They have defined a zone of normal circulatory function (zone CD-EF) from their data. In those individuals falling below the line $\mathrm{CD}$, the work per beat is not commensurate with heart size and patients suffering from congestive heart failure have been shown to lie in this area (Starr $(19,20,21)$, Stewart $(22,23,24))$. In this study we found that every individual in both the group of athletes and the normal (control) group fell within the zone of normal circulatory function (Figure 2). 


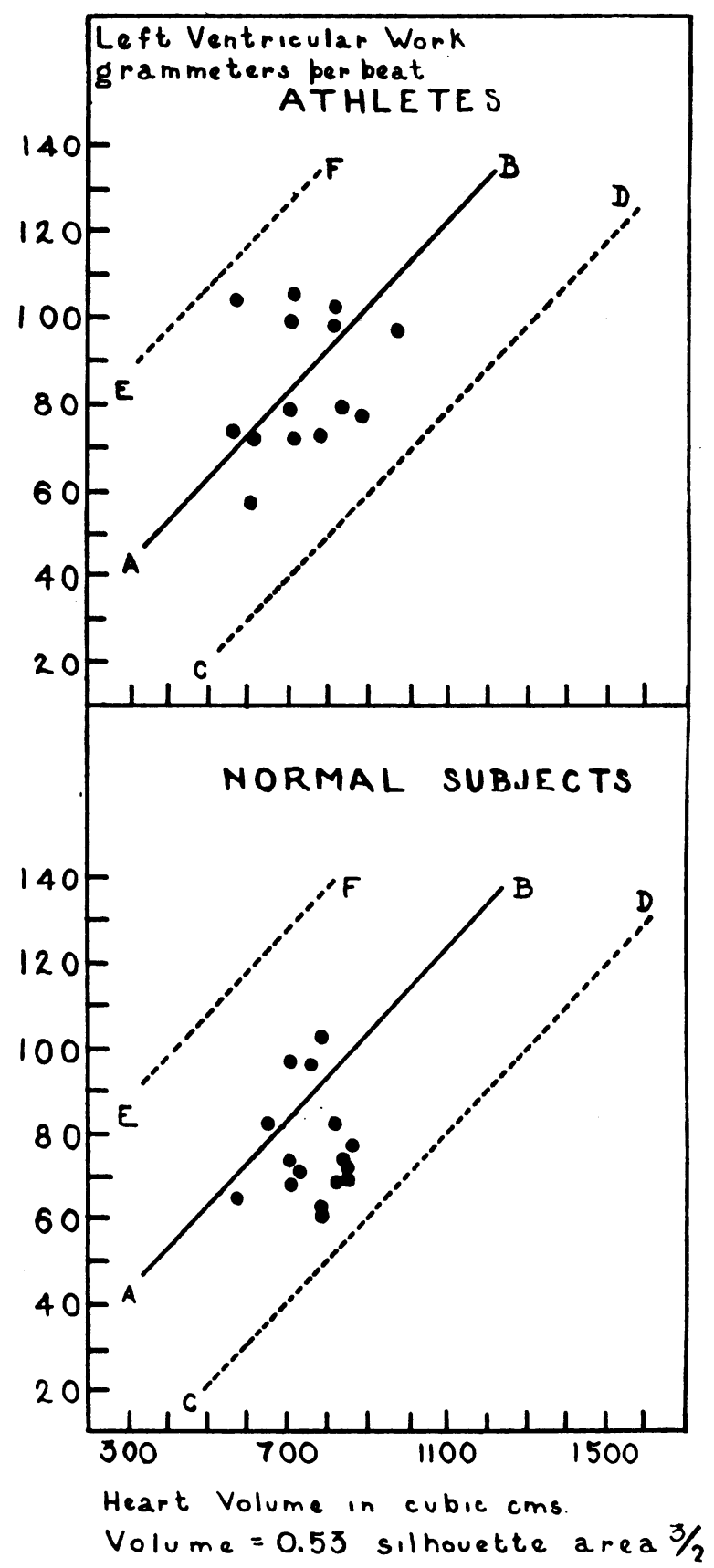

Fig. 2. Left Ventricular Work per Beat and Cardiac Volume

The data from Tables I and II relating to the work of the left ventricle per beat in both the normal group and the athletes are plotted against the corresponding cardiac volumes. Line $A B$ represents the best line, the regression of the work on the area, defined by Starr, Collins, and Wood (19) on the basis of a statistical treatment of data from a control group of cases. Lines CD and EF are placed by these authors at a distance of
The ratio of transverse cardiac diameter to the chest diameter has been used in this study as a measurement of heart size in addition to the heart volume-work correlation. While our findings of a heart of normal size in the group of athletes is in agreement with the work of other observers (1, $3,4,8,25)$, it is not to be inferred from our data that cardiac enlargement does not occur in individuals engaged in more strenuous and prolonged types of exercise such as marathon running.

In this group of athletes, all the electrocardiograms were considered normal. Bramwell and Ellis (12) report "variations" in the form of the $\mathrm{P}$-wave, T-wave, and $\mathrm{R}-\mathrm{T}$ segment, as well as prolongation of the $\mathrm{P}-\mathrm{R}$ interval in electrocardiograms of Olympic athletes. The auriculoventricular conduction time was within the limits of normal in all of our cases and no distinct differences in the form of the records between the control group and athletes were observed. The differences between our findings and those observed by Bramwell and Ellis may be explained on the basis of the types of athletes which were studied in the two reports.

Finally, it should be pointed out again that all of our observations were made while the individuals were in a basal metabolic state. Although these studies reveal no significant differences in the functional capacity of the hearts of the athletes, as compared with the normal subjects who were leading a sedentary life, it does not necessarily follow that the individuals used as controls can perform the same amount of work as efficiently as the athletes.

\section{SUMMARY}

1. Measurements of the arteriovenous oxygen difference, oxygen consumption, minute volume output, stroke volume, vital capacity, cardiac size,

twice the standard deviation from AB. It appears from their observation that an individual falling within the zone CD-EF has a normal circulatory function. That is to say, the work of the heart is commensurate with its size; on the other hand, they found that the values relating to patients who had suffered from cardiac decompensation fell in a zone below CD. Each closed circle in the above figure represents a measurement in that group as indicated. It is apparent that all individuals of both the normal group and the athletes fall well within the zone of normal circulatory function (zone CD-EF). 
circulation time and venous pressure, arterial pressure and heart rate, were made of 14 college athletes and also of 11 healthy, young, adult males who were living a sedentary life and who served as controls. These objective measurements were carried out under basal conditions.

2. With one exception, there was no significant difference between those made on college athletes and those derived from the control group. The stroke volume of the athletes was slightly larger. This difference appears to be related to body size, since the stroke volume per kilogram of body weight and the cardiac index for the two groups are approximately the same.

\section{BIBLIOGRAPHY}

1. Gordon, B., Levine, S. A., and Wilmaers, A., A group of marathon runners; with special reference to circulation. Arch. Int. Med., 1924, 33, 425.

2. Deutsch, F., and Kauf, E., Heart and Athletics. Tr. by Louis M. Warfield. C. V. Mosby and Co., St. Louis, 1927.

3. Farrell, J. T., Jr., Langan, P. C., and Gordon, B., Roentgen ray study of group of long-distance runners, with special reference to effects of exercise on size of heart. Am. J. M. Sc., 1929, 177, 394.

4. Gordon, B., Effects of exercise on circulation and respiration. J. M. Soc. New Jersey, 1930, 27, 672.

5. Paterson, R., and Paterson, E., Experiment on effect of exercise on heart in athletes. Am. J. Roentgenol., 1935, 34, 158.

6. Roesler, H., A roentgenological study of the heart size in athletes. Am. J. Roentgenol., 1936, 36, 849.

7. Keys, A., and Friedell, H. L., Size and stroke of heart in young men in relation to athletic activity. Science, 1938, 88, 456.

8. Richards, T. K., Observations on hearts of men engaged in athletics. J. A. M. A., 1930, 94, 1988.

9. Stewart, H. J., Effect of exercise on size of normal hearts and of enlarged hearts of dogs. J. Clin. Invest., 1929, 7, 339.

10. Bock, A. V., Vancaulaert, C., Dill, D. B., Fölling, A., and Hurxthal, L. M., Studies in muscular activity. III. Dynamical changes occurring in man at work. J. Physiol., 1928, 66, 136.
11. Henderson, Y., Haggard, H. W., and Dolley, F. S., Efficiency of heart, and significance of rapid and slow pulse rates. Am. J. Physiol., 1927, 82, 512.

12. Bramwell, C., and Ellis, R., Some observations on circulatory mechanism in marathon runners. Quart. J. Med., 1931, 24, 329.

13. Steinhaus, A. H., Chronic effects of exercise. Physiol. Rev., 1933, 13, 103.

14. Grollman, A., The Cardiac Output of Man in Health and Disease. Chas. C. Thomas, Springfield, III., 1932.

15. Grollman, A., Friedman, B., Clark, G., and Harrison, T. R., Studies in congestive heart failure. XXIII. Critical study of methods for determining cardiac output in patients with cardiac disease. J. Clin. Invest., 1933, 12, 751.

16. Levy, R. L., Size of heart in pneumonia; Teleroentgenographic study with observations on effect of digitalis therapy. Arch. Int. Med., 1923, 32, 359.

17. Bardeen, C. R., Determination of size of heart by $\mathrm{x}$-rays. Am. Jour. Anat., 1918, 23, 423.

18. Tarr, L., Oppenheimer, B. S., and Sager, R. V., The circulation time in various clinical conditions determined by the use of sodium dehydrocholate. Am. Heart J., 1933, 8, 766.

19. Starr, I., Jr., Collins, L. H., Jr., and Wood, F. C., Studies of basal work and output of heart in clinical conditions. J. Clin. Invest., 1933, 12, 13.

20. Starr, I., Jr., and others, Studies of heart and circulation in disease; estimations of basal cardiac output, metabolism, heart size, and blood pressure in 235 subjects. J. Clin. Invest., 1934, 13, 561.

21. Starr, I., Jr., and others, Clinical study of action of 10 commonly used drugs on cardiac output, work and size; on respiration, on metabolic rate and on electrocardiogram. J. Clin. Invest., 1937, 16, 799.

22. Stewart, H. J., Crane, N. F., Deitrick, J. E., and Thompson, W. P., Action of digitalis in compensated heart disease. Arch. Int. Med., 1938, 62, 547.

23. Stewart, H. J., Deitrick, J. E., Crane, N. F., and Wheeler, C. H., Action of digitalis in uncompensated heart disease. Arch. Int. Med., 1938, 62, 569.

24. Stewart, H. J., Deitrick, J. E., Watson, R. F., Wheeler, C. H., and Crane, N. F., Effect of valvular heart disease on dynamics of circulation; observations before, during and after occurrence of heart failure. Am. Heart J., 1938, 16, 477.

25. Leaman, W. G., Heart and athletics. Internat. Clin., 1934, 3, 1. 